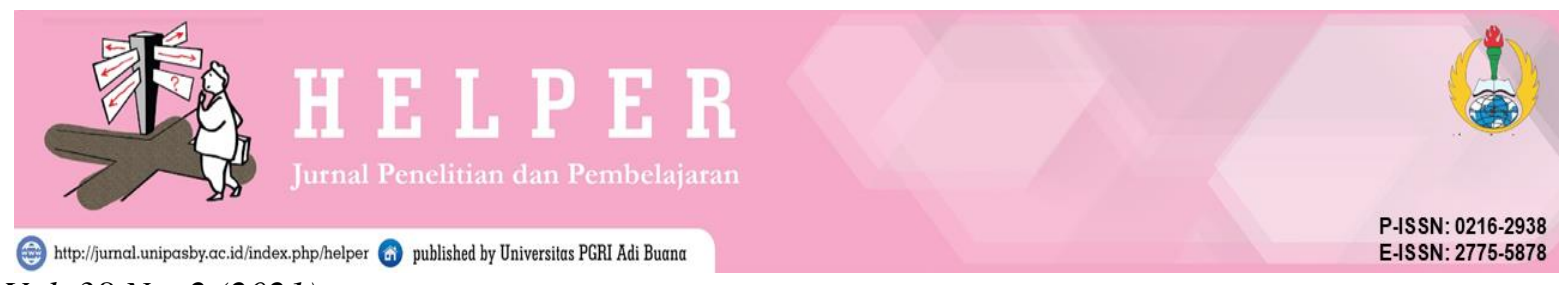

Vol. 38 No. 2 (2021)

\title{
EFEKTIVITAS TEKNIK ROLE PLAYING DALAM KONSELING KELOMPOK UNTUK MENINGKATKAN KOMUNIKASI INTERPERSONAL SISWA KELAS VII SELAMA DARING DI SMP NEGERI 2 KRIAN
}

\author{
Reza Ayunda \\ ${ }^{1}$ Bimbingan dan Konseling, Universitas PGRI Adi Buana Surabaya, Surabaya, Indonesia \\ *Email: ayunda.ra30@gmail.com \\ Aniek Wirastania \\ ${ }^{2}$ Bimbingan dan Konseling, Universitas PGRI Adi Buana Surabaya, Surabaya, Indonesia \\ *Email: aniek@unipasby.ac.id
}

\begin{abstract}
Abstrak
Penelitian ini bertujuan untuk mengetahui tingkat keefektifan teknik role playing dalam konseling kelompok untuk meningkatkan komunikasi interpersonal siswa kelas VII selama daring di SMP Negeri 2 Krian. Rancangan penelitian yang digunakan peneliti adalah One Grup Pre-test Post-test Design, yang kemudian diberikan kepada siswa yang berjumlah 5 anak yang mendapatkan skor rendahsedang. Penentuan sampel ditentukan dengan menggunakan teknik purposive sampling. Peneliti menggunakan teknik analisis data dengan uji Wilcoxon yang termasuk dalam analisis non-parametrik. Hasil penelitian menunjukkan asymp. Sig (2-tailed) sebesar 0,042, karena nilai 0,042<0,05 maka hipotesis diterima. Dengan demikian dapat disimpulkan teknik role playing dalam konseling kelompok secara signifikan dapat meningkatkan komunikasi interpersonal siswa kelas VII selama daring di SMP Negeri 2 Krian.
\end{abstract}

Kata Kunci: Komunikasi Interpersonal, Role Playing, Konseling Kelompok

\footnotetext{
Abstact

This study aims to determine the level of effectiveness of role playing techniques in group counseling to improve interpersonal communication of class VII students while online at SMP Negeri 2 Krian. The research design used by the researcher was the One Group Pre-test Post-test Design, which was then given to 5 students with low-medium scores. Determination of the sample is determined by using purposive sampling technique. Researchers used data analysis techniques with the Wilcoxon test which was included in non-parametric analysis. The results showed asymp. Sig (2-tailed) of 0.042 , because the value of $0.042<0.05$, the hypothesis is accepted. Thus, it can be concluded that the role playing technique in group counseling can significantly improve the interpersonal communication of class VII students while online at SMP Negeri 2 Krian.
}

Keywords: Interpersonal Communication, Role Playing, Group Counseling 


\section{PENDAHULUAN}

Manusia merupakan makhluk sosial artinya manusia selalu membutuhkan pertolongan dari orang lain dan senantiasa ingin berhubungan dengan orang lain. Ada beberapa cara untuk berhubungan dengan individu lain, salah satu caranya adalah berkomunikasi. Komunikasi merupakan suatu kemampuan seorang individu untuk menyampaikan pesan kepada orang lain (Cangara, 2012). Pesan dapat diterima dengan baik apabila ada komunikasi yang jelas dan lancar.

Menurut (Suryanto, 2015) pengertian komunikasi antarpribadi (interpersonal) adalah komunikasi yang dilakukan secara face to face (tatap muka). Komunikasi interpersonal merupakan hal yang sangat berpengaruh bagi siswa apalagi dalam kehidupan bermasyarakat. Komunikasi merupakan kebutuhan bagi setiap individu dalam berinteraksi dan bergaul dengan orang lain, kemampuan komunikasi interpersonal tiap individu berbeda satu sama lain. Kemampuan komunikasi interpersonal selain pengaruh dari diri sendiri, dapat juga dipengaruhi oleh kondisi lingkungan dan situasi. Situasi dan kondisi saat ini yang sedang marak-maraknya virus covid-19 dapat mempengaruhi kemampuan komunikasi interpersonal siswa, hal tersebut dikarenakan para siswa kurang berinteraksi dan berkomunikasi dengan orang lain saat masa pandemi. Covid-19 memiliki beberapa dampak, salah satunya terhadap bidang pendidikan (Andina Amalia, 2020).

Pada masa pandemi semua hal dilakukan secara daring, termasuk sekolah. Pembelajaran daring yang dilakukan secara terus-menerus membuat siswa tidak paham tentang materi yang dijelaskan oleh guru, akibatnya siswa menjadi pasif selama pembelajaran berlangsung. Pembelajaran daring membuat para siswa menjadi pasif. Banyak siswa yang aktif ketika pembelajaran tatap muka, tetapi ketika pembelajaran daring beberapa siswa menjadi pasif. Begitupun dengan siswa yang ketika pembelajaran tatap muka sudah pasif, ketika diberlakukannya pembelajaran daring makin membuat siswa menjadi pasif.

Permasalahan tersebut diakibatkan oleh berbagai faktor, seperti tidak paham dengan penjelasan guru, takut bertanya ketika pembelajaran daring, dan lain sebagainya. Hal tersebut membuat beberapa siswa menjadi tidak paham dengan materi yang sudah dijelaskan, serta berdampak pada kemampuan komunikasi para siswa. Untuk mengatasi hal tersebut bisa dilakukan dengan menerapkan salah satu teknik yang ada dalam BK, yaitu teknik role playing. Teknik role playing adalah teknik dimana siswa bermain peran sesuai dengan situasi yang dialami. Tujuan teknik role playing adalah membantu siswa dalam meningkatkan komunikasi 
Efektivitas Teknik Role Playing Dalam Konseling Kelompok Untuk Meningkatkan Komunikasi Interpersonal Siswa Kelas VII Selama Daring Di SMP Negeri 2 Krian

interpersonal, membantu siswa dalam memahami diri dan menganalisis perilaku (Herlina, 2015).

Teknik role playing dapat digunakan untuk berbagai layanan, seperti konseling individu, bimbingan kelompok dan konseling kelompok. Dalam hal ini peneliti menggunakan layanan konseling kelompok.Konseling kelompok adalah suatu bentuk layanan dalam BK yang membantu konseli melalui dinamika kelompok, bantuan ini diberikan oleh konselor yang bertujuan untuk menyelesaikan masalah dari setiap siswa. Menurut Hamalik dikutip dari (Yulia Safitri, 2017) teknik role playing yang diterapkan dalam konseling kelompok dapat meningkatkan rasa empati, sikap terbuka, dan melihat orang lain setara tanpa membedakan latar belakang.

Penelitian ini bertujuan untuk mengetahui signifikansi efektivitas teknik role playing dalam konseling kelompok untuk meningkatkan komunikasi interpersonal siswa kelas VII selama daring di SMPN 2 Krian. Berdasarkan latar belakang yang sudah dipaparkan oleh peneliti, peneliti merasa terdorong untuk melakukan penelitian tentang "Efektivitas Teknik Role Playing dalam Konseling Kelompok untuk Meningkatkan Komunikasi Interpersonal Siswa Kelas VII Selama Daring di SMP Negeri 2 Krian“.

\section{METODE}

Penelitian ini menggunakan metode kuantitatif. Rancangan penelitian yang digunakan peneliti adalah eksperimen One Group Pre-test Post-test Design (Sugiyono, 2017). Desain tersebut terdapat uji pre-test yaitu uji yang diberikan sebelum siswa mendapatkan treatment dan uji post-test, yaitu uji yang diberikan sesudah siswa mendapatkan treatment.

Penelitian ini mengambil populasi dari kelas VII-F di SMPN 2 Krian yang berjumlah 43 siswa, tetapi karena dari 43 siswa yang mengisi google formulir hanya 15 siswa, maka peneliti menggunakan 15 siswa tersebut sebagai populasi. Sampel yang digunakan oleh peneliti berjumlah 5 siswa yang ditentukan dengan teknik purposive sampling. Teknik purposive sampling adalah teknik yang digunakan oleh peneliti untuk menentukan sendiri sampel yang akan diteliti (Sugiyono, 2017).

Peneliti menggunakan metode pengumpulan data berupa kuisioner komunikasi interpersonal. kuisioner sebelum disebarkan kepada siswa, terlebih dahulu harus di uji validasi yang kemudian dilanjutkan dengan uji pre-test yang disebarkan melalui google formulir. Metode analisis data yang digunakan oleh peneliti berupa uji Wilcoxon dengan menggunakan SPSS for 
Efektivitas Teknik Role Playing Dalam Konseling Kelompok Untuk Meningkatkan Komunikasi Interpersonal Siswa Kelas VII Selama Daring Di SMP Negeri 2 Krian

windows versi 24.0. Peneliti menggunakan uji Wilcoxon karena sampel yang diteliti kecil, yaitu berjumlah 5 siswa.

\section{HASIL PENELITIAN DAN PEMBAHASAN}

\section{Hasil Penelitian}

Penelitian ini dilakukan di salah satu sekolah yang ada di Krian, yakni SMPN 2 Krian. Pelaksananan penelitian dimulai dari tanggal 24 Desember 2020 - 02 Februari 2021. Dibawah ini adalah penjabaran hasil penelitian sudah dilakukan oleh peneliti.

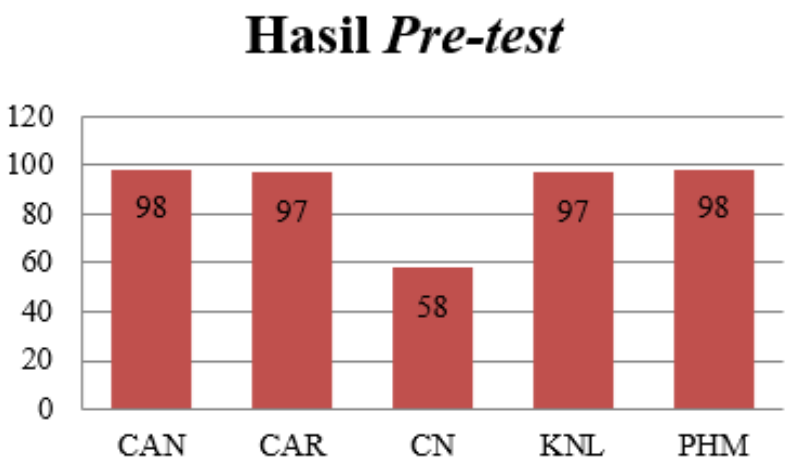

Gambar 1. Hasil Skor Pre-test Komunikasi Interpersonal Siswa Kelas VII-F

Berdasarkan grafik pre-test diatas dapat dilihat bahwa terdapat 5 responden memiliki komunikasi interpersonal dengan skor rendah-sedang. Terdapat responden yang mendapatkan skor terendah yaitu CN dengan skor 58, CAR dan KNL mendapatkan skor 97 yang masuk dalam kategori sedang, kemudian ada CAN dan PHM yang mendapatkan skor 98 masuk dalam kategori sedang. Hasil pre-test ini menunjukkan keadaan awal sebelum siswa mendapatkan treatment. Setelah diperoleh hasil pre-test, siswa yang termasuk ke dalam kategori rendahsedang akan dijadikan sebagai subjek penelitian, yang mana selanjutnya akan diberikan treatment yang menggunakan teknik role playing dalam konseling kelompok.

Setelah diketahui hasil pre-test dari siswa, langkah selanjutnya adalah memberikan treatment yang berupa layanan konseling kelompok dengan menggunakan teknik role playing untuk membantu siswa dalam upaya meningkatkan komunikasi interpersonal yang rendah. Treatment dilakukan sebanyak 6 kali pertemuan. 


\section{Hasil Post-test}

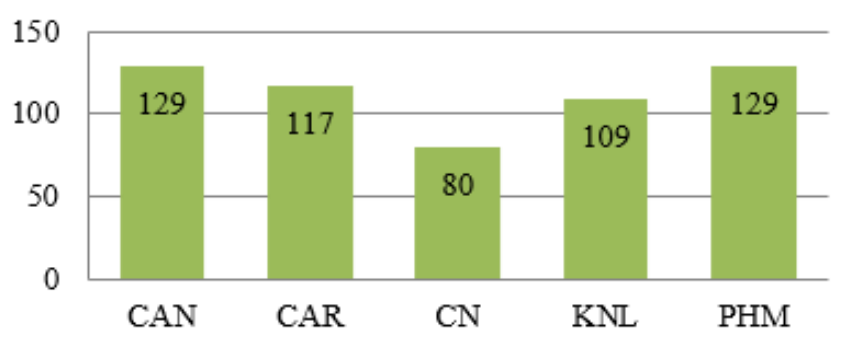

Gambar 2. Hasil Skor Post-test Komunikasi Interpersonal Siswa Kelas VII-F

Berdasarkan hasil skor post-test pada gambar grafik di atas menunjukkan 5 siswa yang sudah mengalami perubahan dalam komunikasi interpersonal setelah diberikan treatment. Hasil skor post-test menunjukkan adanya peningkatan dari skor nilai sebelumnya yang rendahsedang menjadi sedang-tinggi dengan skor 80-129.

\section{Hasil Pre-test dan Post-test}

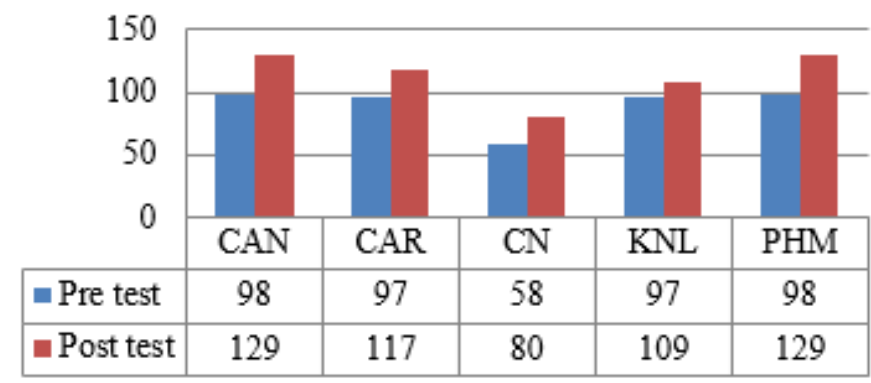

Gambar 3. Hasil Perbandingan Pre-test dan Post-test Komunikasi Interpersonal Siswa Kelas VII-F

Berdasarkan gambar 3 diatas menunjukkan bahwa setiap siswa berada pada kategori rendah-sedang, kemudian presentase pada setiap siswa mengalami peningkatan menjadi kategori sedang-tinggi. Hasil post-test yang telah diberikan kepada 5 siswa menunjukkan adanya peningkatan hasil yang telah dicapai oleh kelima siswa.

Konseli CN mendapatkan skor pre-test sebesar 58 yang termasuk kategori rendah, kemudian $\mathrm{CN}$ diberi treatment dan mengalami peningkatan pada hasil post-test yaitu sebesar 80 yang termasuk dalam kategori sedang.

Konseli PHM mendapatkan skor pre-test sebesar 98 yang termasuk kategori sedang, kemudian PHM diberi treatment dan mengalami peningkatan pada hasil post-test yaitu sebesar 129 yang termasuk dalam kategori tinggi. 
Efektivitas Teknik Role Playing Dalam Konseling Kelompok Untuk Meningkatkan Komunikasi Interpersonal Siswa Kelas VII Selama Daring Di SMP Negeri 2 Krian

Konseli CAR mendapatkan skor pre-test sebesar 97 yang termasuk kategori sedang, kemudian CAR diberi treatment dan mengalami peningkatan pada hasil post-test yaitu sebesar 117 yang termasuk dalam kategori tinggi.

Konseli KNL mendapatkan skor pre-test sebesar 97 yang termasuk kategori sedang, kemudian KNL diberi treatment dan mengalami peningkatan pada hasil post-test yaitu sebesar 109 yang termasuk dalam kategori tinggi.

Konseli CAN mendapatkan skor pre-test sebesar 98 yang termasuk kategori sedang, kemudian CAN diberi treatment dan mengalami peningkatan pada hasil post-test yaitu sebesar 129 yang masuk dalam kategori tinggi.

Metode analisis data yang digunakan dalam penelitian ini adalah uji Wilcoxon. Berikut ini adalah hasil perhitungan uji Wilcoxon yang akan dijelaskan pada tabel 1.

Tabel 1. Hasil Perhitungan Uji Wilcoxon Komunikasi Interpersonal Siswa Kelas VII-F

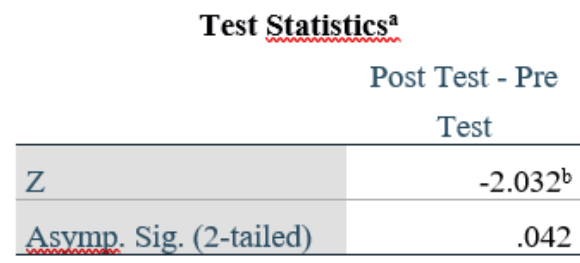

a. Wilcoxon Signed Ranks Test

b. Based on negative ranks.

Berdasarkan tabel 1 hasil uji Wilcoxon diperoleh Sig. (2-tailed) sebesar 0,042, karena $0,042<0,05$ maka dapat ditarik kesimpulan yaitu hipotesis diterima.

\section{Pembahasan}

Penelitian ini menggunakan 5 siswa yang dijadikan sampel yang selanjutnya akan dilakukan uji pre-test dengan menyebarkan kuisioner yang telah dibuat oleh peneliti. Pre-test yang telah dilakukan oleh siswa menunjukkan bahwa komunikasi interpersonal siswa selama pembelajaran daring dalam kategori rendah-sedang. Setelah melakukan uji pre-test, selanjutnya peneliti akan melakukan treatment dengan menggunakan teknik role playing dalam konseling kelompok. Pelaksanaan treatment dilakukan sebanyak 6 kali pertemuan dengan topik permasalahan yang berbeda-beda setiap siswa.

Treatment ini dilakukan dari tanggal 30 Desember 2020 - 01 Februari 2021. Treatment pada pertemuan pertama membahas tentang permasalahan siswa yang tidak berani bertanya kepada guru saat pembelajaran daring. Hal tersebut dikarenakan siswa takut salah dalam 
Efektivitas Teknik Role Playing Dalam Konseling Kelompok Untuk Meningkatkan Komunikasi Interpersonal Siswa Kelas VII Selama Daring Di SMP Negeri 2 Krian

bertanya yang akan mengakibatkan ditertawakan oleh teman-temannya, dari permasalahan tersebut pemimpin kelompok mengajak para siswa untuk melakukan pemeranan dengan menggunakan teknik role playing. Hal ini bertujuan untuk meningkatkan komunikasi interpersonal serta memunculkan keberanian siswa dalam bertanya saat pembelajaran daring.

Treatment pada pertemuan kedua membahas tentang permasalahan siswa yang grogi saat dimintai guru untuk menjawab pertanyaan saat pembelajaran daring. Hal tersebut dikarenakan siswa takut salah dalam menjawab, dari permasalahan tersebut pemimpin kelompok mengajak para siswa untuk melakukan pemeranan dengan menggunakan teknik role playing. Hal ini bertujuan untuk meningkatkan komunikasi interpersonal, memunculkan keberanian, serta kepercayaan diri siswa dalam bertanya saat pembelajaran daring.

Treatment pada pertemuan ketiga membahas tentang permasalahan siswa yang tidak berani berbicara didepan umum. Hal tersebut dikarenakan siswa tidak percaya diri serta bingung akan mau berbicara apa ketika tampil didepan umum, dari permasalahan tersebut pemimpin kelompok mengajak para siswa untuk melakukan pemeranan dengan menggunakan teknik role playing. Hal ini bertujuan untuk meningkatkan komunikasi interpersonal serta memunculkan keberanian siswa.

Treatment pada pertemuan keempat membahas tentang permasalahan siswa yang cenderung pasif saat daring. Hal tersebut dikarenakan siswa tidak paham dengan penjelasan guru ketika pembelajaran daring serta tidak berani bertanya karena bingung mau berkata apa, dari permasalahan tersebut pemimpin kelompok mengajak para siswa untuk melakukan pemeranan dengan menggunakan teknik role playing. Hal ini bertujuan untuk meningkatkan komunikasi interpersonal serta memunculkan keberanian siswa.

Treatment pada pertemuan kelima membahas tentang permasalahan siswa yang takut salah untuk mengeluarkan pendapat. Hal tersebut dikarenakan siswa takut pendapat yang diutarakan tidak dihargai oleh teman-temannya, dari permasalahan tersebut pemimpin kelompok mengajak para siswa untuk melakukan pemeranan dengan menggunakan teknik role playing. Hal ini bertujuan untuk meningkatkan komunikasi interpersonal serta memunculkan keberanian siswa.

Treatment pada pertemuan keenam membahas tentang usaha apa yang dilakukan dan hasil apa yang sudah dicapai oleh setiap siswa serta mengevaluasi pertemuan I sampai pertemuan V. Pertemuan keenam ini peneliti menemukan ada 2 siswa yang sudah melakukan usahanya untuk mengatasi permasalahan yang ada pada dirinya, meskipun siswa tersebut masih 
Efektivitas Teknik Role Playing Dalam Konseling Kelompok Untuk Meningkatkan Komunikasi Interpersonal

takut tetapi setidaknya sudah ada usaha yang dilakukan. Hal tersebut tentu saja baik untuk siswa, karena siswa sudah mau melakukan proses perubahan.

Treatment yang sudah dilakukan kemudian peneliti melakukan uji post-test. Uji posttest dilakukan dengan menyebarkan kuisioner tentang komunikasi interpersonal yang kemudian akan diisi oleh kelima siswa, setelah siswa selesai mengisi kuisioner langkah selanjutnya adalah peneliti menjumlahkan total skor yang didapatkan. Hasil uji post-test kemudian dibandingkan dengan hasil uji pre-test yang selanjutnya di analisis menggunakan uji Wilcoxon. Peneliti menggunakan uji Wilcoxon dikarenakan sampel yang diteliti relatif kecil. Hasil uji Wilcoxon menunjukkan bahwa terjadi peningkatan nilai rata-rata (mean score) komunikasi interpersonal pada $\mathrm{N}=5$. Nilai mean sebelum diberikan layanan konseling kelompok dengan teknik role playing sebesar 89,60 dengan nilai standar deviasi sebesar 17,672, sedangkan setelah diberikan layanan konseling kelompok dengan teknik role playing nilai mean meningkat menjadi 112, 80 dengan standar deviasi sebesar 20,200.

Hasil interpretasi menggunakan uji Wilcoxon diketahui bahwa asymp. Sig (2-tailed) sebesar 0,042, karena nilai 0,042 < 0,05 maka dapat disimpulkan bahwa Ho ditolak dan Ha diterima. Dengan demikian dapat disimpulkan bahwa teknik role playing dalam konseling kelompok secara signifikan dapat meningkatkan komunikasi interpersonal siswa selama daring kelas VII di SMP Negeri 2 Krian.

Hal tersebut relevan dengan beberapa penelitian yang terdahulu, seperti penelitian yang dilakukan oleh Safitri, Yusmansyah, dan Utaminingsih yang berjudul "Penggunaan Layanan Konseling Kelompok Teknik Role Playing Untuk Meningkatkan Komunikasi Interpersonal Siswa Kelas XI SMAN 8 Bandar Lampung Tahun Ajaran 2016/2017” yang menggunakan penelitian kuantitatif dengan metode penelitian one group pre-test post-test design. Penelitian tersebut menghasilkan data yang menunjukkan bahwa terdapat perbedaan yang signifkan antara kemampuan komunikasi interpersonal siswa sebelum dan setelah diberikan layanan konseling kelompok teknik role playing. Hal ini menunjukkan bahwa teknik role playing dalam konseling kelompok efektif untuk meningkatkan komunikasi interpersonal siswa.

Penelitian yang relevan juga dilakukan oleh (Nurul Lailiyah, 2020) Nurul Lailiyah dan Muslim Afandi yang berjudul "Efektivitas Teknik Role Playing Dalam Layanan Konseling Kelompok Untuk Meningkatkan Komunikasi Interpersonal Siswa" yang menggunakan penelitian kuantitatif dengan metode penelitian one group pre-test post-test design. Penelitian tersebut menghasilkan data yang menunjukkan bahwa teknik role playing dalam layanan 
Efektivitas Teknik Role Playing Dalam Konseling Kelompok Untuk Meningkatkan Komunikasi Interpersonal Siswa Kelas VII Selama Daring Di SMP Negeri 2 Krian

konseling kelompok dapat diterapkan untuk mengatasi komunikasi interpersonal siswa. Hal ini menunjukkan bahwa teknik role playing dalam konseling kelompok efektif untuk meningkatkan komunikasi interpersonal siswa.

\section{KESIMPULAN}

Berdasarkan penelitian yang telah dilakukan oleh peneliti, bisa ditarik kesimpulan bahwasannya konseling kelompok yang menggunakan teknik role playing efektif untuk meningkatkan komunikasi interpersonal siswa. Hal tersebut dapat dibuktikan dari adanya perubahan skor siswa antara skor pre-test (sebelum diberikan treatment) dan post-test (sesudah diberikan treatment) yang mengalami peningkatan.

Menurut paparan yang sudah dijelaskan di atas, penulis dapat memberi saran bagi pihak-pihak yang berhubungan dalam permasalahan ini. Saran-saran in dapat digunakan sebagai acuan bagi pihak-pihak yang terkait. Adapun Saran-saran yang dapat diberikan antara lain.

1. Bagi peneliti diharapkan dapat mengembangkan penelitian ini dengan cara menambah jumlah sampel siswa yang akan digunakan sebagai bahan penelitian. Peneliti diharapkan dapat memahami dan mempelajari teknik serta layanan yang akan digunakan dalam penelitian.

2. Bagi orang tua diharapkan untuk lebih memperhatikan perkembangan anak, apalagi pada masa pertumbuhan dimana pada masa ini anak lebih membutuhkan perhatian dan kasih sayang orang tua. Terlebih lagi dalam pergaulan sehari-hari.

3. Bagi siswa harus sadar dan memahami betapa pentingnya komunikasi interpersonal bagi diri sendiri, apalagi pada masa pandemi covid-19 yang menyebabkan banyak siswa yang menjadi pasif dikarenakan kurangnya sosialisasi dengan orang lain.

4. Bagi sekolah diharapkan lebih memperhatikan para siswa yang kurang dalam hal komunikasi interpersonal, serta diharapkan bagi Guru BK untuk menerapkan teknik-teknik yang bisa membantu meningkatkan komunikasi interpersonal siswa, seperti teknik bermain peran (role playing).

\section{UCAPAN TERIMA KASIH}

Saya mengucapkan terima kasih kepada pihak-pihak yang terkait, khususnya siswa-siswi yang bersedia menjadi subjek penelitian saya. 
Efektivitas Teknik Role Playing Dalam Konseling Kelompok Untuk Meningkatkan Komunikasi Interpersonal

\section{DAFTAR PUSTAKA}

Andina Amalia, N. S. (2020). Dampak Pandemi Covid-19 Terhadap Kegiatan Belajar Mengajar di Indonesia . Jurnal Psikologi, 214-225.

Cangara, H. (2012). Pengantar Ilmu Komunikasi. Jakarta: RajaGrafindo Persada.

Herlina, U. (2015). Teknik Role Playing Dalam Konseling Kelompok. Jurnal Pendidikan Sosial, 2, 94-107.

Nurul Lailiyah, M. A. (2020). Efektivitas Teknik Role Playing Dalam Layanan Konseling Kelompok Untuk Meningkatkan Komunikasi Interpersonal Siswa . Administrasi Pendidikan dan Konseling Pendidikan, 67-72.

Sugiyono. (2017). Metode Penelitian. Bandung: Alfabeta.

Suryanto. (2015). Pengantar Ilmu Komunikasi. Bandung: Pustaka Setia.

Yulia Safitri, Y. D. (2017). Penggunaan Layanan Konseling Kelompok Teknik Role Playing Untuk Meningkatkan Komunikasi Interpersonal Siswa Kelas XI. 68-81. 